\title{
THE ROLE OF UNESCO HERITAGE IN THE BOUTIQUE TOURISM OFFER IN SLOVENIA
}

\author{
Jasna Potočnik Topler \\ Lea Kužnik ${ }^{2}$
}

DOI: https://doi.org/10.31410/tmt.2019.629

\begin{abstract}
Cultural heritage is a significant co-creator of the tourist offer, especially if it carries the prestigious title of a UNESCO World Heritage Site. UNESCO's heritage strengthens national identity and is universally recognisable. The particularity of Slovenia is the fact that only the Škocjan Caves are among the main tourist attractions of the destination as an example of a UNESCO (natural) Heritage Site. All other UNESCO Heritage Sites in Slovenia are less known, but they represent the foundation for the development of boutique and exclusive tourist offers and boutique tourism in contrast to mass tourism, which is challenging at many destinations which brand themselves as UNESCO Heritage Sites since they are very often facing overtourism.
\end{abstract}

Slovenia is ranked on the UNESCO World Heritage List with the following Heritage Sites: The mercury heritage (mercury mine in Idrija), prehistoric catches at the Ljubljana Marshes, and natural heritage - the Škocjan Caves, the ancient and primaeval beech forests in the Krokar jungle, and the Snežnik Żdrolce reserve. On the UNESCO representative list of the intangible cultural heritage of humankind, there are tours of the Kurent traditional masks, the drywall construction, lace knitting and Processio Locopolitana (the Škofja Loka Passion Play). The inclusion of heritage into a modern tourist offer requires reflection and a professional approach. What is good for protecting and preserving the heritage is not necessarily good for tourism, and what is good for tourism is rarely appropriate for heritage protection. Therefore, the integration of heritage in the tourism offer, the creation of heritage-based models, is a matter of strategic design and professional decisions. In the chapter it will be analysed how, or in what way, the UNESCO heritage in Slovenia is included in the modern tourist offer. This will be determined by employing field work, the technique of partially structured interviews with stakeholders who protect and explore the selected heritage, and tourist providers who interpret heritage in various ways and incorporate it into modern (boutique and exclusive) tourist offers. We will also obtain information through the analysis of websites and field visits to the UNESCO Heritage Sites. In doing so, we will highlight examples of good practices for each UNESCO heritage case. On this basis, it will be determined what are the possibilities and opportunities for integrating the UNESCO heritage into the modern boutique tourist offer of Slovenia.

Keywords: heritage, heritage tourism, UNESCO, tourism offer, Slovenia.

\section{INTRODUCTION}

Cultural heritage is a significant co-creator of the tourist offer, especially if it carries the prestigious title of a UNESCO World Heritage Site. UNESCO's heritage strengthens national identity and is universally recognizable. Of course, it needs to be emphasized that the concept of heritage and cultural heritage has changed and evolved through time (Vecco, 2010). Nowadays, heritage is no longer defined on the basis of its material aspect. This development has enabled the recognition of intangible cultural heritage, which was ignored for a long time, as heritage to be protected and safeguarded (Vecco, 2010). Also, Bogataj $(1992,11)$, defines cultural heritage

\footnotetext{
University of Maribor, Faculty of Tourism, Cesta prvih borcev 36, 8250 Brežice, Slovenia

2 University of Maribor, Faculty of Tourism, Cesta prvih borcev 36, 8250 Brežice, Slovenia
} 
as something that has been created outside of the natural action of nature or from it, whereby the heritage is not only the monuments, but all those cultural elements that have been preserved in different forms in the past, or at least they are known as forms of lifestyle of the past. A significant part of the natural heritage is, in its basic essence, cultural heritage, so, not only the conscious and deliberately designed natural environment, but also everything created by the men in this environment or from it. Cultural heritage involves various relationships between men and their cultural environment, and answers questions about who we are, where we come from and where we belong (Jezernik, 2010, 196). Cultural heritage is significant for the local and regional environments, especially if it carries the prestigious title of UNESCO World Heritage.

Slovenia is ranked on the UNESCO World Heritage List with the following Heritage Sites: The mercury heritage (mercury mine in Idrija), prehistoric catches at the Ljubljana Marshes, and natural heritage - the Škocjan Caves, the ancient and primaeval beech forests in the Krokar jungle, and the Snežnik Ždrolce reserve. On the UNESCO representative list of the intangible cultural heritage of humankind, there are tours of the Kurent traditional masks, the drywall construction, lace knitting and Processio Locopolitana (the Škofja Loka Passion Play). The particularity of Slovenia is the fact that only the Škocjan Caves are among the main tourist attractions of the destination as an example of a UNESCO (natural) Heritage Site. All other UNESCO Heritage Sites in Slovenia are less known, but they represent - according to the directions of the Strategy of the Sustainable Growth of Slovenian Tourism 2017-2021 (Strategija, 2017) the foundation for the development of boutique and exclusive tourist offers, and Boutique Tourism in contrast to mass tourism, which is challenging at many destinations which brand themselves as UNESCO Heritage Sites, since they are very often facing overtourism.

The inclusion of heritage into a modern tourist offer requires reflection and a professional approach. What is good for protecting and preserving the heritage is not necessarily good for tourism, and what is good for tourism is rarely appropriate for heritage protection. Therefore, the integration of heritage in the tourism offer, the creation of heritage-based models, is a matter of strategic design and professional decisions.

In the chapter, will be analysed how, or in what way, the UNESCO heritage in Slovenia is included in the modern tourist offer. The subject of the research is topical, since heritage is an important co-creator of our future. The discovery, exploration, scientific research and tourism experience of heritage, along with its preservation, help to strengthen the identity of the nation, the sense of belonging and dialogues between cultures. According to Lenzerini $(2011,103)$ »appropriate safeguarding of the international cultural heritage of the diverse peoples making up the world - is essential for promoting harmony in intercultural relations, through fostering better appreciation and understanding of the differences between human communities«. Due to all these factors, 2018 was proclaimed European Year of Cultural Heritage. This one-year project successfully contributed to the increased awareness about the importance of cultural heritage.

\section{METHODOLOGY}

The research is founded on a literature review, combined with field work, participant observation during the tours around the Škocjan Caves and the Idrija Mercury Mine, and the technique of unstructured interviews with stakeholders who protect and explore the selected heritage (the Škocjan cave, the Krokar virgin forest, the Idrija Mercury Mine), and tourist providers who interpret heritage in various ways and incorporate it into modern (boutique and exclusive) tourist 
offers. Some information was also obtained through the content analysis of websites. The following research question will be answered in this chapter: In which ways is the UNESCO heritage in Slovenia included in the modern tourist offer? Further on, we will highlight examples of good practices in Slovenia for each UNESCO heritage case. On this basis, we will determine what are the possibilities and opportunities for integrating UNESCO heritage into the modern boutique tourist offer of Slovenia.

\section{INTERPRETATION OF CULTURAL HERITAGE}

An essential part of including cultural heritage into the tourism offer is its interpretation. When interpreting cultural heritage, it is not just about giving information, but primarily about discovering the meaning, influencing attitudes and behaviors, and attracting interest. Interpretation should be informative, raising awareness, enriching knowledge and arousing interest in finding new insights about the environment, and, therefore, if it wants to be of good quality, it must always be based on real facts and authentic stories. In fact, in this respect, it also differs from tourist animation, where it is important that tourists are entertained (Handbook for the interpretation of cultural heritage, pp. 4-5). A good interpretation of cultural heritage must be appropriate. This means that it relies on the knowledge and experience of visitors, so it is necessary to check their interest and expectations constantly. A good interpretation must be well researched and diverse, that is, based on modern research work, as well as folk tradition, and to persuade visitors in different ways, depending on the different learning styles and the use of different media, taking into account demographic and cultural characteristics. If information about the heritage is presented in an attractive, unusual way, full of challenges, and the motivation for learning something new is high, learning about the heritage takes place in a playful and fun way. It is also important that the interpretation is comprehensive, with all the elements in a particular environment, sustainable and inclusive. It is good to include and link all stakeholders in the process of heritage management and conservation. In the preparation of interpretive techniques, both heritage experts and the local community must be involved. In this context, it is important to take into account the values of local communities and visitors, and, on this basis, to plan different ways of providing information that is not intrusive or harmful to the environment in which a particular heritage is located.

The means for interpreting cultural heritage are diverse. There exist interpreting centres where various presentations of heritage are held for visitors, such as workshops for craftsmen, culinary workshops for the preparation of local specialties, use of lecture rooms, social spaces, halls for various purposes and events etc. Furthermore, there are outdoor museums that are preserved in the state they were in at a given period of time in order to display the „moment in time”. This means that only a particular object or multiple objects are preserved, but their function is also interpreted from the past or the way it operates. The ,theater of history" is also an effective means of interpretation, where life situations from the past are staged. In this regard, authenticity (costumes, use of language, appropriate rules of behavior and mutual relations with the way of work, tasks) is very important, which is shown through various scenes of rituals, celebrations, habits and customs, performances of people from the past... Demonstration is also an effective means of interpretation (Handbook for the interpretation of cultural heritage, b. d, pp. 16). It can take place in a completely contemporary context, although old knowledge, skills or procedures are displayed and interpreted. Often it is about displaying day-to-day tasks in a modern way of life, such as a cow's machine milking, which is as interesting to visitors as manual milking of cows. In interpreting workshops, which distinguish themselves from demonstrations in that 
the visitors participate actively and, at the same time, learn certain skills, they learn their own skills creatively. Most common are the following tasks: Mowing with a scythe, harvesting with a sickle, weaving on looms, lace-knitting or knitting baskets etc.

Storytelling is the oldest and most effective form of interpretation, the primary environment for this is in the evening at the bonfire, the winter evening at the stove, the fireplace, or the inn. Fog, Budtz, Munch and Blanchette (2010, pp. 31-32) enumerate the key elements of the story that form the essence of storytelling. These are: The message, the conflict, characters, and the course of the story. In storytelling, the emotional component is exposed and it becomes a very important tool for achieving various goals. Especially in the tourism sector, it serves as an important tool that conveys the message about the specified destination (Kužnik and Veble, 2018, pp. 43).

Culinary experiences can also be used as a very effective means of interpretation. They include all senses, smell and taste, but remain in the long-term memory. Interpretations are not carried out only through food and drink, but also through menus, food settings, ways of serving, guided culinary tours and the like. With the help of culinary experiences, interpretation can be extremely effective in achieving different interpretive goals. Various brochures are classified as the most commonly used interpretation medium. They serve as an addition to their own field research. Their weakness is that tourists and visitors discard them quickly.

Instead of leaflets, the visitor can use the manual for self-guided tours on the selected route, on which the individual elements and locations that we want to interpret are marked with numbers, and the main interpretation is provided in the manual. The user guide can be supplemented with route journals, a pre-prepared publication that combines a handbook, and empty pages where the visitors put their impressions, observations, photos, stamps... Interpretation boards are irreplaceable at the starting and key points of the thematic routes, but, nevertheless, they are far from effective insofar as their use is widespread. The board is a sensible means of interpretation when it comes to topics that visitors can experience in the immediate surroundings alone, or if it is to explain the complex phenomena that everyone should understand. It is important that the text is short and concise.

The board can be replaced by audio visual means at reference points as an audio backdrop for the transmission of sound effects, voices, noise... Audio-visual means, among which are multivisions, movies, shows, internet, etc., are very effective means of interpretation, they provide information, generate mood, emotional responses and ethical views of people. In modern times, postcards are often forgotten, and they also communicate important messages about the place, the area, the heritage, the way of life. An excellent means of interpretation are souvenirs, and especially useful, and very topical, are also culinary souvenirs (Handbook for the interpretation of cultural heritage, b. d., pp. 14-20). Regardless of the choice of interpretive techniques and means, the interpretation is successful when the visitor senses, feels, and experiences the heritage at his/her own pace and style.

\section{EXPERIENCE TOURISM}

Tourism is an activity that is changing and adapting to new needs and trends constantly. The modern tourist is no longer satisfied with the sightseeing of the places and sights that they are visiting, but wants to experience a lot of new, different, interesting things on their travels. The 
modern tourist wants experience, contacts with the local population, their way of life, culture, habits and customs, local cuisine etc. They also search for various activities and want to become part of the local events. Today's tourist is no longer satisfied only with observing natural and cultural heritage and attractions, but simply wants to participate actively in the daily and festive way of life of the locals. Experiences are the main motive for people to travel. Because of different experiences, the trips are unique and invaluable (https://www.thetravelword.com/, 3.5.2018).

Experiences come in many colors and shapes. Experience is a meeting with a group of children in the African countryside, a sunrise over the mountain, a descent into a cave, a visit to a local wine cellar with tasting wine and culinary specialties, a holiday at a tourist farm where guests take care of pets, fishing with the local people, dancing with locals, weaving on looms, watching bears etc. The experience tourist is eager for new adventures, is spontaneous and ready for active leisure time. We distinguish two forms of experiential tourism: A soft and a hard shape (Swarbrooke, 2003, 33). We talk about a soft form when it is less risky and tourists do not need previous experience. Soft forms also require less psychological effort than hard forms. The wider concept of experiential tourism represents Alternative Tourism, which is the opposite of Mass Tourism. It is a step away from Mass Tourism such as sea-sun-beach. Later, Alternative Tourism was also associated with the concept of Ecological (Mihalič, 1999, 319) and Boutique Tourism, the development of which is based on the natural and cultural heritage of Slovenia and all of its experiences.

\section{NATURE EXPERIENCE}

\subsection{The Škocjan Caves}

The Škocjan Caves are a natural phenomenon of exceptional global value, set alongside the Grand Canyon, the Great Coral Relief, the Galapagos, and Mount Everest. The Škocjan Caves, the largest ever known underground canyon in the world, which is up to 146 meters high, has several kilometers of walking path with 500 steps, 26 underground waterfalls, caves of all shapes and sizes, some up to 15 meters high. The guide in the Škocjan Caves, Aleš Iulita, explained that this is a case of contact Karst, which developed at the contact between flysch and limestone. In a small area, numerous Karst phenomena have developed (sinks, natural bridges, ravines, buns, collapses, abysses, underground canyons, trenches, springs etc.). Part of the Škocjan Caves is called Velika and Mala dolina. Due to the special microclimate conditions, the two valleys developed an exceptional ecosystem in which Mediterranean and alpine elements intertwine. For example, the alpine meadows (such as the Avrique) and the Mediterranean flora (such as the ferns of venereal larvae) grow close together. The great valley is the classic site of Justin's Bells (Campanula Justiniana), which grows only in south-west Slovenia (endemic plant), and bats stand out among the endangered animal species. The area also has a great cultural-historical significance, since it was inhabited from the Mesolithic (https://www.park-skocjanske-jame.si/informacije/certifikati\#a_UNESCO, 1.5.2019). The long-term coexistence of nature and man is reflected in the typical Karst cultural landscape and building heritage. The area is also important because of the fundamental research of Karst and Karst phenomena from the 17th century (Valvasor) to the present (more in Mihevc, et. al 2016, 82).

The Great and the Little valleys and the underground canyon are examples of exceptional natural beauty, and have a great aesthetic meaning on a global scale. For this reason, on 28 November 1986, the Škocjan Caves entered into the UNESCO World Heritage List. The number 
of visitors is increasing every year; in 2018 there were around 200,000, where we can still talk about Boutique Tourism compared to the Mass Tourism in the Postojna Cave, which is visited by one million tourists a year (Aleš Iulita, personal communication, 23.4.2019). The Škocjan Caves in the modern tourist offer include mainly guided caves. An additional activity is a thematic learning path, where participants learn about the special features of the classical Karst. The symbol of the learning path is a drop which guides direct and acquaint visitors with the natural phenomena and cultural heritage. Visitors are involved actively. They can also engage actively in thematic workshops, with content coming from nature, the former way of life and heritage in the park area. The modern tourist offer also includes museum collections (Zbirka zgodovine raziskovanja Škocjanskih jam, ethnological collection in the Jakopin barn and geological collection of stones in the Delez homestead). The Park also provides cycling routes.

\subsection{First beech forests in Slovenia}

The areas of the earliest beech forests of the Carpathians and other European regions listed in the UNESCO World Heritage List are the best-preserved parts of beech forests, that have played an important role in the development and impact of beech ecosystems in Europe since the last Ice Age 12,000 years ago. At that time, only the beech forests in southern Europe, which began to spread throughout Europe, managed to survive the frost, bringing with it the entire ecosystem, thousands of species of animals and plants. Among these areas there are also forest reserves in Pragozd Krokar (the virgin forest Krokar) and Snežnik - Ždrolce. Krokar is located in the heart of the Kočevje forest. In this virgin forest, the human hand has not yet encroached, but it is home to indigenous species of beasts and birds. Ancient beech forests, which have secured their place on the UNESCO list with their preservation, can also be found in the Snežnik Ždrolce Reserve. Slovenian beech forests are listed on the list of the world's natural heritage along with beech forests in Ukraine, Slovakia, Germany, Albania, Austria, Belgium, Bulgaria, Croatia, Italy, Romania and Spain. All forests together bear the name Beech forests of the Carpathians and other European regions (http://www.mizs.gov.si, 20.4.2019, www.slovenia. info, 20.4.2019). In the interview, Nevenka Klun from the Tourism and Cultural Centre Kočevje explained that the virgin forest Snežnik - Ždrolce is offered to tourists in the form of a guided tour only by a district forester, since it is a home to autochthonous beasts and birds.

\section{EXPERIENCE THE LIFE OF THE PEOPLE}

\subsection{First pile dwellings on the Ljubljana Marsh and the oldest wooden wheel with an axe in the world}

Slovenia is one of the countries that hold the protected world heritage of prehistoric pile dwellings around the Alps (besides Austria, France, Germany, Italy, Switzerland). On the Ljubljana Marsh, 40 sites with pile dwelling remains were discovered; nine piles in two groups entered the UNESCO list (https://whc.UNESCO.org/en/list/1363, 23.4.2019). The Ljubljana Marsh is a natural swampy area measuring 160 square kilometers, where there are 100 different species of birds, 90 species of butterflies, deer, otters. In prehistoric times, the majority of the Marsh was covered by a shallow lake, surrounded by pile dwellers. The most important find of archeological sites on the Ljubljana Marsh is a wooden wheel with an axe, which is almost 5,150 years old, and considered the oldest in the world. The wheel and the axe were part of a two-wheeled train, or some kind of cue to be hauled by cattle. It was made from various types of wood, and perfected technically by a top prehistoric master (http://www.ljubljanskobarje.si, 11.4.2019). Various 
objects related to the way of life of pile dwellers are on display at the Ljubljana City Museum, the National Museum of Slovenia, and at the permanent exhibition Pile dwellers from the large lake on Ig. The oldest wooden wheel with an axe in the world is stored in the Ljubljana City Museum, and the exhibition also travels around the world a lot.

\subsection{The Mercury Mine in Idrija}

Idrija is, together with the Spanish Almaden, a protector of a world-class heritage of mercury mining, as revealed in the interview with the guide Jože Pavšič (personal communication, 14.7.2018). The Idrija Antoni's tunnel from 1500 is famous as one of the oldest entrances to the mines in Europe (http://www.visit-idrija.si, 12.4.2019). On guided tours, the visitor gets acquainted with the old ways of mining, customs and habits of miners, and their way of life. In the mine they can also encounter the mischievous Bergmandl leprechaun. Before going to the mine, visitors are dressed in a special mining suit with a helmet, and they also take a miner's snack into the cave. The heritage of mining and the life of former mining families is also associated with other special features of Idrija, such as the Gewerkenegg Castle, in which the City Museum Idrija is located, the shaft of Franciscan with renewed mining machines, smeltery, mining theater, the Idrija mining house, the tradition of the original lace knitting etc.

\subsection{Lace knitting}

Lace-knitting is hand-made lace-making by crossing, twisting and interlacing threads wound on special wooden sticks. When knitting, one follows a pattern drawn on a paper that is attached to a cylindrical cushion in a basket, or a special pedestal. Bobbin lace is a unique expression of art, which is one of the recognizable symbols of Slovenian identity. The most famous lace school was founded in Idrija in 1876, and, since then, it has been operating continuously. From here comes the famous Idrija bobbin-lace. Idrija miners' women were commonly engaged with the local handicrafts of lace, since lace brought them a permanent source of additional earnings. Initially, lace was made from a coarse, linen thread, intended for the domestic market: The decoration of churches and liturgical clothing, and the furnishings of homes and clothing pieces of a wealthy peasant man. Later, traders entered foreign markets with them, and achieved the highest awards at world exhibitions. Today, more than 120 societies and groups operate in Slovenia (https://ich. UNESCO.org., 2.5.2019). In modern times, lace is a fashion accessory and decoration on clothing and house textiles, and also serves as an inspiration for artistic creation, architecture, and even culinary arts. Today, Idrija lace presents a challenge to well-known fashion designers, artists and other creators. They are placed in the modern tourist offer with a highly respected international Idrija Bobbin-lace Festival, dedicated to the traditional crafting of crafts. The main message of the Festival is innovation and creativity in the use of lace in modern times and space.

\subsection{Drywall construction}

The art of drywall construction, know-how and technique is listed on UNESCO's intangible cultural heritage. Drywall construction is a construction method where a binder is not used. This is the basic and original technique of construction in the Karst region, and reflects the attitude of the Karst man to earth and stone. Strength is provided in the special way of stacking. In Slovenia, dry walls exist only in the Karst and Istria. Despite the loss of the useful value of dry walls, its aesthetic aspect is very important, and represents one of the potentials for tourism in the Karst landscape (http://www.mk.gov.si, 2.5.2019). In the modern tourist offer, dry-stone construction 
is included with the Festival called Kraška gmajna, where various expert discussions, education and round tables are taking place in the field of cultural, nature conservation and tourist aspects of drywall construction. Free drywall construction workshops are also organized.

\subsection{The Kurent visits}

The visits of the Kurent are recorded on the list of UNESCO's intangible cultural heritage of mankind. The Kurent is the most recognizable and traditional carnival character, typical of Ptuj, Dravsko polje, Haloze and Slovenske gorice. It is dressed in sheepskin, has a characteristic mask with a leather face on its head, wears boots, red knit socks, and a cow bell for its belt. With its jumping it makes a noise, chasing away the winter and all the bad things. It is wearing a handkerchief, and a thick stick with a hedgehog skin. On the stick it puts the handkerchiefs given to it by girls. The companion of the Kurent is a devil. The Kurents have their roots in the Slavic mythology (Gačnik and Bogataj, 2004). During the carnival times they walk from house to house in groups, bury winter, call spring into the country and a good harvest (Miha Bobnar, personal communication, 27.2.2019). They are included excellently in the modern tourist offer within the framework of the annual Kurentovanje Festival in Ptuj, which will take place for the 60th time in the year 2020.

\subsection{Processio Locopolitana (the Škofja Loka Passion Play)}

Processio Locopolitana (the Škofja Loka Passion Play) is the oldest drama text in the Slovenian language, dating from 1721. It was written by Father Lovrenc Marušič, who worked in Škofja Loka. The manuscript is preserved in the Capuchin monastery (Boža Grafenauer, personal communication, 2.4.2019). From the very beginning, during the Baroque period, it has been performed in the streets of the medieval core of Škofja Loka. Rich costumes and scenography and a numerous, more than 900-member local acting cast, during every staging in Škofja Loka attract a lot of visitors. It is a historical performance, which takes place every six years due to its complexity. The next performance will take place in 2021 (http://www.pasijon.si, 3.4.2019). The Śkofja Loka Passion Play is the largest theater performance in the open air in Slovenia, proclaimed a living masterpiece of national importance.

\section{DISCUSSION AND CONCLUSION}

All trips include experience of the unusual, beautiful, mysterious, inspiring, etc. What is essential in tourism is the subjective positive impression that stays after the tourist's visit (Potočnik Topler et al., 2017). That is why this positive impression needs to be incorporated into tourism planning to enable a good and positive experience for tourists. Tour guides play a significant role in this part of the creation of the tourist experience (Potočnik Topler et al, 2017).

On the world tourism map, Slovenia wants to position itself as a „green, active and healthy” boutique destination offering world-class tourist five-star experiences. This is also especially relevant in connection with the natural and cultural heritage. Thus, this chapter deals with the creation of tourism experiences based on natural and cultural heritage, and the ways of integrating these tourism products into the modern tourist offer. The content analysis of web pages and the analysis of conducted unstructured interviews with the representatives of different stakeholders at tourism attractions sites, (tourist guides in the Škocjan Caves and the Mercury Mine in Idrija, a local tourist guide in the Karst region, the head of the Kočevje Tourism and Culture Center, a member 
of the Association of the Kurents, and a Professor from the College of Tourism and Hospitality in Bled), analysis of participant observations and participation in guided field tours, has shown that all tourist providers of UNESCO's cultural heritage use various contemporary interpretive techniques in accordance with the expert recommendations regarding the specifics of the location and the specifics of natural or cultural heritage. Therefore, it can be concluded that all activities are planned professionally, and most suitable for a specific natural or cultural heritage site.

In the context of the UNESCO heritage, the Škocjan Caves are one of the main tourist attractions of Slovenia. Nevertheless, the evaluation of attraction managers and guides is that, in Slovenia, Boutique Tourism still exists, and has potential for further development. The visit to the Škocjan Caves is regulated by the number of daily entries of groups in the caves. All other UNESCO Heritage Sites in Slovenia are less known; therefore, they have excellent opportunities for the development of a Boutique Tourism offer and Boutique Tourism. This is also one of the main goals of the Tourism Development Strategy 2017 -2021 in Slovenia.

Nevertheless, the problem of successful integration of the natural and cultural heritage into the tourist offer can be reflected in combining the two systems, heritage and tourism, which usually think and act in a different way. Tourism attracts visitors, markets, and sometimes considers short-term profits as much as possible, without taking into account the protection of places and heritage from damage, pollution, or even destruction. Heritage, on the other hand, often has exactly the opposite role, striving for protection, restoration and preservation for future generations. In doing so, it can be closed and seldom inaccessible, especially if it is „stored” in a museum with limited operating time.

The research of the inclusion of UNESCO's heritage into the modern tourist offer also showed that innovative experiences are those that need to be considered when interpreting heritage to visitors. Experiences are a trend in modern tourism, not products. Experiences must be authentic, personalized, exclusive, but nevertheless accessible, but not to crowds of visitors. In particular, it is about respecting personal interests, expectations, desires and respect for heritage, which must be presented in a modern and innovative way. In the context of personalized experiences, we can point out the Ljubljana Castle as an example of good practice.

The fact of modern tourism is also that tourists watch and rate the destination through the camera of a mobile phone. This is especially true for the UNESCO World Heritage, which finds itself in different applications at a glance. The exception is the Škocjan Caves, where, in the forefront, there is an experience without a telephone since photography and recording are prohibited in the caves because of the negative effects on the caves' flora and fauna. For the other seven examples of the UNESCOs heritage, modern technologies, especially in connection with smartphones, have great untapped potential.

Heritage is a significant component of the everyday and festive life of people, the basis of the boutique tourist offers and dialogue between cultures, the source and inspiration for contemporary expression and creation in all areas of human life. Heritage inspires, motivates and draws innovative ideas for modernity, also with the employment of modern technologies, which can help to present, market and preserve the rich heritage Slovenia as a destination has to offer. Of course, modern technologies and new media are not the only things destination managers should rely on - the key are still professionals in tourism, who have relevant and state-of-the-art knowledge of the specific areas in tourism. 


\section{REFERENCES}

Fog, K., Budtz, C., Munch, P., Blanchette, S., 2010. Storytelling, Branding in Practice. Belin Heidelberg: Springer - Verlag.

Gačnik, A., Bogataj, J. 2004. Dediščina kurenta v kulturi Evrope: etnološko muzeološki vidik. Ptuj: Znanstvenoraziskovalnosredišče Bistra.

Handbook for the interpretation of cultural heritage (Priročnik za interpretacijo kulturne dediščine b.d.). Ljubljana: Ministrstvo za šolstvo in šport.

Kužnik, L., Veble, N. 2018. Into the dark - Dark Stories in the Cities of Brežice and Krško in Slovenia as a Basis for the future Dark Tourism Products, International Journal of Tourism Cities, Vol. 4, No. 1, 40-53.

Lenzerini, F. 2011. Intangible Cultural Heritage: The Living Culture of Peoples, European Journal of International Law, Vol. 22, No. 1, February 2011, 101-120. Retrieved from: https:// doi.org/10.1093/ejil/chr006, 5. 4. 2019.

Mihalič, T. 1999. Poslovanje in ekonomika turističnih podjetij. Ljubljana: Ekonomska fakulteta.

Mihevc, A., Gabrovšek, F., Knez, M., Kozel, P., Mulec, J., Otoničar, B., Petrič, M., Pipan, T. Prelovšek, M., Slabe, T., Šebela, S., Zupan - Hajna, S. 2016. Karst in Slovenia. Boletin Geologico y Minero. Vol. 127, No. 1, 79-97.

Potočnik Topler, Jasna, Zubanov, Violeta, Gorenak, Mitja, Knežević, Mladen. 2017. Communication skills in the tourism sector: the role of tour guides in presenting attractions. Tourismos, Vol. 12, No. 1, str. 59-78.

Strategija, 2017. Strategija trajnostne rasti slovenskega turizma 2017 - 2021. Strategy of the sustainable growth of Slovenian tourism 2017-2021. Retrieved from: http://www.mgrt.gov.si/ fileadmin/mgrt.gov.si/pageuploads/Strategija_turizem_koncno_5.10. 2017.pdf, 4. 5. 2010.

Swarbrooke, J. 2003. Adventure tourism. Oxford: Linacre house.

Vecco, M. 2010. A definition of cultural heritage: From the tangible to the intangible. Journal of Cultural Heritage. Vol. 11, No. 3., 321-324.

Zelnik, D., Štembal, M. 2008. Ohranitev kraške krajine kot razvojna priložnost Krasa. Zbornik referatov in razprav. Ljubljana: Državni svet Republike Slovenije.

https://www.thetravelword.com/, Accessed on 3.5.2018

https://www.park-skocjanske-jame.si/informacije/certifikati\#a_UNESCO, Accessed on 1.5.2019

http://www.visit-idrija.si, Accessed on 12.4.2019

http://www.mk.gov.si, Accessed on 2.5.2019

https://whc.UNESCO.org/en/list/1363, Accessed on 23.4.2019

http://www.mizs.gov.si, Accessed on 20.4.2019

http://www.slovenia.info, Accessed on 20.4.2019

https://ich.UNESCO.org, Accessed on 2.5.2019

http://www.ljubljanskobarje.si, Accessed on 11.4.2019

http://www.pasijon.si, Accessed on 3.4.2019 